\title{
BLACK BRITISH STUDIES IN THE VICTORIAN PERIOD
}

\author{
By Audrey Fisch
}

WHEN I WAS ASKED by the editors of Victorian Literature and Culture to write a review essay assessing current trends in what they called the field of Anglo-African literature, I was delighted but I was also a little skeptical. First, I wondered how they or I would define such a field. Second, I wondered whether the field was in fact so well-established as to embody its own set of trends as opposed to merely consisting of a bunch of people plugging away at their different pieces of work.

It's difficult trying to define the contours of Anglo-African studies, or what others call black British studies, since the terms "Anglo-African" and "black" are such historically specific and loaded terms. But an unnuanced and period-specific definition, which I think is the best I can do, might be the study of the relation between Victorian society and the variety of peoples originating in the African continent and living variously in the West Indies, in the United States, in Africa, and in England proper. The Victorians, it should be said, wouldn't have neatly categorized all of these diverse populations into one cultural category (unlike many Americans today who would pronounce all these people to be "black").

However imprecisely one defines it, black British studies or black British Victorian studies (the latter an unwieldy mouthful) is one piece of the larger study of Victorians and race. And the broader field of race and the Victorians is a vast and complex entity from which it is difficult to segment off a smaller self-contained set of texts and arguments. In the muddled intersection between the larger study of Victorians and race and black British studies we've had a number of important books. Douglas Lorimer's seminal Colour, Class and the Victorians: English Attitudes to the Negro in the Mid-Nineteenth Century (1978) is more than two decades old. Patrick Brantlinger's Rule of Darkness: British Literature and Imperialism (1988) and Peter Fryer's Staying Power: The History of Black People in Britain (1984) go back almost as far and have had similar long-ranging impact. Important work from the early-to-mid-nineties includes Edward Said's Culture and Imperialism (1994), Catherine Hall's White, Male and Middle Class: Explorations in Feminism and History (1992), and Robert Young's Colonial Desire: Hybridity in Theory, Culture and Race (1995). 
Notwithstanding this phenomenal body of work, I remain pessimistic about how well established black British Victorian studies is and how thoroughly this work is permeating the overall field of Victorian studies. Lorimer's book, for example, is out of print, which means it is hardly likely to be the required reading for Ph.D. exams that I think it deserves to be.

A quick glance at the latest (2000, seventh edition) Norton Anthology of English Literature suggests how far we still need to go in terms of integrating questions of race into the teaching of Victorian studies. The important Victorian issues which get their own subject-oriented sections remain "Evolution," "Industrialism: Progress or Decline?" and "The Woman Question: The Victorian Debate about Gender." Slavery and colonialism, for example, have evidently still not been established as important Victorian issues. Carlyle and Mill's debate on the Negro/Nigger Question is not among the selected readings. Nor are the narratives of Mary Prince or Mary Seacole. The slavery poems of Elizabeth Barrett Browning are also not among the selections. Finally, the first volume of the Norton acknowledges slavery as an important issue with a section entitled "Slavery and Freedom" and selections from Equiano, Ignatius Sancho, Laurence Sterne, and Samuel Johnson. But for Romanticists and Victorianists, the second volume offers little improvement in this area.

So the Norton anthology doesn't reflect the broad understanding of Victorian culture that I want it to. So what? We all know anthologies never represent the cutting edge of scholarship. The problem is that my students' only exposure to the Victorian period comes from a survey of the Romantic/Victorian period, and I am required to teach that survey with the Norton (and my students cannot afford to buy supplemental texts). Since many of my students are going on to teach secondary and elementary school, mostly in urban environments, the political ramifications of the Norton's omissions are troubling.

Some years from now, when black British studies in the Victorian period is more firmly established, the scholarship that I'm examining in this essay, and the work that comes after it, will have reshaped the Norton. And I'll be able to find those selections on slavery and race and imperialism in the Victorian issues section that I can't find now.

In the meantime, I have the responsibility of doing that work for my students. So as I read the latest scholarship, I have my students in mind. Of course I have my own scholarly interests, and I read to see where my own work stands in relation to developments in the field. More broadly, I read looking for ways to transform my teaching of the field. I want fresh readings of the canon, certainly. But I also want to be provoked by readings of more obscure texts, which I may or may not have encountered (and which I may or may not be able to xerox surreptitiously for my students). My reading in the field is determined by my search for materials that will allow me to show my students that Victorian society was shaped by many of the same, mostly ugly conflicts about race and power that they encounter in their lives.

$$
* * *
$$

SIMON GIKANDI POSITIONS his Maps of Englishness as an attempt to supplement Raymond Williams's seminal Culture and Society (1963). Gikandi writes that since Williams had not explored how the "crisis in the central definition of English identities in the 
nineteenth century ... was intricately connected to colonialism and, by extension, to the decline of the British state in the period after decolonization," Culture and Society "ended up creating an interpretive impasse" (xii). Maps of Englishness, then, is "an attempt ... to read Englishness as a cultural and literary phenomenon produced in the ambivalent space that separated, but also conjoined, metropole and colony" (xii).

Gikandi looks at Carlyle and Mill's Negro/Nigger exchange; puts Mary Seacole's Wonderful Adventures in conversation with Mary Kingsley's Travels in West Africa; offers an interesting discussion of travel writing about the West Indies featuring Anthony Froude's The English in the West Indies, Anthony Trollope's The West Indies and the Spanish Main, and Charles Kingsley's At Last: A Christmas in the West Indies; contrasts Conrad's "An Outpost of Progress" and Heart of Darkness with Graham Greene's Journey Without Maps; and discusses the "colonized subject's own relation to the culture of colonialism once the imperial referent has collapsed" (48) through Joan Riley's The Unbelonging and Salman Rushdie's The Satanic Verses.

Gikandi's arguments are unevenly useful to Victorianists, particularly those of us who work on the Victorians and race. For example, he writes of Mary Seacole's Adventures that

beneath Seacole's optimistic portrait of the colonial subject in the service of empire (and the tone of Wonderful Adventures is clearly celebratory) lies the author's barely suppressed sense of crisis, a crisis about her own identity and authority. Seacole ostensibly writes her narrative to call attention to the role she had played in England's imperial drama in Central Europe, but she also writes, against the background of her post-Crimea obscurity and destitution, to demand recognition as an Englishwoman. (142)

As he explains, "Seacole, unlike Miss Florence Nightingale, cannot take her English identity, or her role as a Crimean heroine, for granted: she has to etch it in the public consciousness by writing a narrative" (142). These kinds of insights are certainly valid and important, but I suspect that to anyone who has taught Seacole, and particularly to anyone who has any background at all in the slave narrative tradition and has read Seacole in this context, such arguments are pretty obvious. As I mentioned earlier, given Seacole's absence in the Norton and the ways in which Victorian studies has traditionally bracketed off writers of color, many of Gikandi's readers may find his arguments quite new.

Gikandi directly addresses the question of what his audience may or may not know in his discussion of Carlyle and Mill.

Everyone knows that Thomas Carlyle and John Stuart Mill are two of the most important icons of English culture in the nineteenth century, but very few people know of the centrality of black subjects in their discourses on the national character. (57)

Given this assumption about his readers, Gikandi provides a very sensible and useable discussion of the two texts. Without equating "Mill's liberalism with Carlyle's nascent fascism" (68), he argues that for both writers "any sustained contemplation of blackness is also an act of self-reflexivity: it is through the black figure that Englishness acquires the metaphorical structure that enables it to gaze at its self in crisis" (69). But what are we to 
make of Gikandi's assumption here that "very few people" know about the "centrality of black subjects" to Carlyle and Mill?

To my mind, the strongest element of Gikandi's book is his discussion of what he calls the "culture of travel" (84). Juxtaposing texts by Trollope, Froude, and Charles Kingsley, Gikandi examines the relation between "English identity, theories of alterity, and imperial travel" (87) in order to argue, for example, that "the traveler can measure the character of the English nation in crisis [domestically] against the romance of 'pure' imperialism" (105) in the West Indies. Gikandi writes that "the claim to facticity and the authority of the eyewitness is what makes the narrative of imperial travel different from the Carlylean spectacle" (90-91), and he cites Trollope and others who claim that "those who have been to the West Indies [unlike Mill and Carlyle] can discuss its affairs 'in light' of their experiences" (91). Eventually, however, Gikandi finds that "touring becomes a form of retour: opinions formed before the commencement of the voyage are not dissipated by experience; on the contrary, they are authorized by the weight of personal observations" (117). The journeys "would appear to be gratuitous"; they begin with "anxieties about the metropole" which are then contained and resolved through the travel narratives by writers who with "a certain enunciative authority [of] the traveler" address the "domestic audience" to produce "a sublime affirmation of Englishness" (117).

In his second chapter, Gikandi extends his argument about black alterity in the service of English affirmation to reflect on the relation between Enoch Powell's "deployment of alterity" and Carlyle's racist spectacles. From the nineteenth to the twentieth century, Gikandi asks, has

the black other been transformed (in relation to the English domestic space) from a transcendental subject to what Sartre would call an "empirical person"? ... As an "empirical person" whom we encounter in our streets and neighborhoods, the black ... functions as a presence - a subject who claims the authority of sameness — our cultural heritage and noesis. (74)

Not surprisingly, Gikandi concludes that black others can continue to serve as an "imaginary presence" (80), as "figures of alterity that would reinforce Englishness" (74), even as they become a larger literal presence in England. After all, literal encounters for Trollope, Kingsley, and Froude didn't produce vastly different readings of "blackness." Indeed, their lack of travel to the colonies notwithstanding, Carlyle and Mill had access to the literal presence in England of a small population of blacks which did not seem to have any impact on their deployment of blacks as figures in the Victorian imagination. Ultimately, according to Gikandi, "blackness" is used by all these writers to re-define and bolster crises of Englishness.

A good deal of this book, particularly the section on Rushdie and some of the discussion of Conrad's "metacommentary on the status of the aesthetic in the social sphere" (167), moves beyond the Victorian period, leaving me dissatisfied as a Victorianist eager to see Gikandi do more to explore the vast areas of Victorian society and culture, such as Victorian travel, that I still do not know enough about. Another text that clearly bridles at the limitations of traditional periodization is Kathleen J. Renk's Caribbean Shadows and Victorian Ghosts: Women's Writing and Decolonization. Renk reads the fiction of Jamaica Kinkaid, Dionne Brand, Jean Rhys, Erna Brodber, and Michelle Cliff, arguing that Anglophone Caribbean women needed to write new narratives that could 
bury the ghosts of the mythical colonial family. Renk explains that "in rejecting literary realism and nationalist rhetoric based on English models, in a sense burying Victorian ghosts and Victorian discourse, these writers begin to unearth new narratives that move the nations closer to decolonization" (9).

There is no denying the connections between these Caribbean writers and the Victorian period. Many of us, I would venture, have managed to find a way to teach Wide Sargasso Sea next to Jane Eyre, and we are eager to think about new connections between the texts we are so familiar with and these fascinating, later revisions. But while the blurb on the back of her book asserts that Renk reads this contemporary fiction "alongside British texts such as Dickens's Great Expectations and Brontë's Jane Eyre," Victorianists, I think, will be disappointed by what they find about the Victorian period in this book.

Renk begins with the "ideal nineteenth-century middle-class English family" which "acquired mythological connotations as . . . an isle of stability": namely, "the moral and intellectual father, the angelic, asexual mother, and the dutiful child whose character has been shaped by the moral strength of his parents" (7-8). This family, Renk argues, came to serve "as a paradigm for the English-colonial relationship"; "the superior, moral, 'enlightened' parental country ... and the inferior, acquiescent, 'uncivilized' but cheerfully submissive child country" (8). This English-colonial family, Renk contends, "continued to serve as a paradigm for colonial, Commonwealth countries long after Victoria's empire reached its zenith" (8). But while the myth of the colonial family may have held enormous ideological power in the Caribbean, Renk concedes that in actuality "Victorian gentlewomen did not subscribe to this 'myth' ... of the angel of the house; instead they traveled, wrote, and created and were often actively involved in the community" (36). So the struggle, in her postcolonial texts, is more against the nineteenth-century narrative than against any reality.

That said, Renk's characterizations of these Victorian narratives are sometimes simplistic. For example, she says that her Caribbean writers "rewrite mystifying and damaging Victorian and Edwardian representations that embody monolithic, static views of women" (91). Elsewhere, Renk writes that "the classic realist text ... perpetuate[s] static configurations of gender, race or color" (152). As examples of this trend, Renk cites Miss Havisham and Bertha Mason, explaining that these are characters who "stagnate in madness" in contrast to the characters in contemporary texts which reenvision "the nineteenth-century representation of madness and transform the so-called mad female figure into a figure of rebellious, socially transformative power ... [who] uses her unconscious mind to educate and transfigure herself and others" (93). Given the wonderful, wide-ranging recent criticism on Jane Eyre that focuses on Bertha, it is odd to hear her described as a "static," monolithic representation of anything. Indeed, when Renk writes that "Brontë characterizes Bertha as a "morally-insane colonial beast" who must be morally managed in the Victorian home," Renk seems to fall into the basic trap of reading realist fiction, which is to conflate the character's viewpoint (in this case Rochester's) with the novelist's. Bertha's character, her madness, and the relationship between the former and colonialism, is clearly one of the least static and most unsettling aspects of Brontë's novel. Surely, recent contemporary criticism on Brontë's "madwoman in the attic" seems to bear this out. Moreover, the genius of Rhys's Wide Sargasso Sea, it seems to me, is that it reads not so much as a transformation or criticism of Jane Eyre but as a series of missing chapters, coextensive with the complexity of the original novel and of the very non-static character of Bertha. 
In the end, Renk seems to need the Victorians to be the static, monolithic ghosts who can be transformed by her "new literatures by women, the women on whose backs the empire was built and ... [whose] literature will help transform the world's consciousness and remake the world" (153). But this optimistic narrative of progression, charming as it may be, is precisely what Gikandi and Anne McClintock in her book Imperial Leather are working to resist. In the end, Renk seems to find her complexity in the contemporary novelists she examines, and not in the Victorian ones. That means that for a Victorianist looking to throw in a piece of contemporary fiction at the end of a survey class in order to draw connections and draw outward, much of Renk's book is surprisingly uninspiring. Admittedly, for those more broadly interested in postcolonial literature, Renk's work is probably more compelling than it is for me.

Contemporary criticism of Jane Eyre leads me to Susan Meyer's book, Imperialism at Home. Meyer argues that Bertha's coloring, her imprisonment, her identity as a Creole (that is, a person, black or white, born in the West Indies) all function to associate Bertha with the "'dark races' in the empire, particularly African slaves" (72). In a brilliantly nuanced and elegantly argued chapter, Meyer investigates Brontë's "complex metaphorical use of race" (64) in Jane Eyre. She argues that the novel "produces some suggestions ... that British imperialism in the West Indies and in India has been damaging, as well as some intimations that the accumulation of British wealth from colonial sources is a stain on the nation's history" (26). And while Meyer acknowledges that Brontë kills off Bertha in an attempt to "clean" (84) the moral stench and stain of colonialism and slavery from England and the English, Meyer reads the ambiguity and "uneasiness" of the ending of the novel to argue that Brontë's "lingering anxiety about British imperialism and about her own literary treatment of other races" (95) remains a potent, contradictory impulse within the novel's quest for a clean, happy ending.

This reading of Jane Eyre is one piece of Meyer's larger study of the ways in which Charlotte Brontë, Emily Brontë, and George Eliot "use race metaphorically in their fiction as they explore issues of gender" (7). Meyer sets her project in contrast to Patrick Brantlinger's work, disputing his argument that "most of the domestic fiction of nineteenth-century Britain ultimately affirms imperialist ideology" and countering that "the social positioning of various writers of the domestic novel ... put them in different relation to the project of empire" (9). Specifically, Meyer argues that "the gender positioning of British women writers required them to negotiate an association with "inferior races"' and that "their feminist impulses to question gender hierarchies often provoked an interrogation of race hierarchies" (11). For Meyer, it is "precisely the gender positioning of these women writers in British society, in combination with their feminist impulses and their use of race as a metaphor, that provoked and enabled an (albeit partial) questioning of British imperialism" (11) and a "surprisingly forceful critique of empire" (28).

Meyer examines Charlotte Brontë's African juvenilia and Jane Eyre, Emily Brontë's Wuthering Heights, and George Eliot's The Mill on the Floss and Daniel Deronda. Her book, rather incontrovertibly, complicates the grand narratives of ideological complicity and empire identification of Brantlinger, Said, and others. As Meyer claims by the end of her book, the "fictional workings" of the writers she has studied are "considerably more subtle and complicated" (201). Her elegant, detailed, and careful chapters make that point convincingly. But Meyer's historically informed and politically nuanced readings of these three canonical writers (and okay, she does look at C. Brontë's relatively unexamined 
juvenilia) remains a very small project. Even Meyer's overall argument about the impact that gender has on the positioning of British women writers in relation to imperialism seems a bit overstated based only on the small evidence of her three cases.

Meyer nearly raises this point in her introduction when she asks, "Why then does this book focus in particular on the fiction of Charlotte Brontë, Emily Brontë, and George Eliot?" (24). As an answer she says only that "it would seem logical to look for an interest in race in the fiction of some of the women novelists of nineteenth-century England who manifest the most overt discontent with the constraints of gender" (24). The answer, for me, continues to beg the question.

Moreover, there is little in this book about what difference these three individual women's writings had in the larger world they inhabited or in the larger political upheaval they were interrogating with their figurative imaginings. Only in her discussion of Daniel Deronda does Meyer briefly gesture outward at the uses of Eliot's novel by Zionist Jews in the 1880s. And here her discussion is far less extensive than Reina Lewis's work on responses to Daniel Deronda in Gendering Orientalism: Race, Femininity and Representation. Lewis provides illuminating analysis of how Eliot's book was probably read by the Victorians, regardless of what Eliot may have intended for her audience or of what readings the text itself might enable for Victorianists today.

In the end, Meyer makes no argument that these were significant texts in terms of their influence on Victorian culture. Nor does she articulate the case that the ideas in these texts are necessarily representative of larger Victorian discourses. She seems to take for granted that whatever she may find in these three canonical writers will, a priori, be important to our understanding of gender, race, and Victorian culture. But is it?

Jennifer DeVere Brody's Impossible Purities: Blackness, Femininity, and Victorian Culture forms an interesting corrective to Meyer's Imperialism at Home. Brody raises a slightly different set of questions than does Meyer. Brody asks, "How and why did the English become 'white'? Or rather, how did Victorian texts construe Englishness as 'masculine,' 'white,' and 'pure'?” (9). In answering her questions, Brody turns to a broad spectrum of Victorian culture, in sharp contrast to Meyer's far more selective investigation of the domestic novel and its relation to empire. Brody explains that her materials must range far beyond Victorian canonical literature:

To investigate the extent to which Victorian publics may have been familiar with representations of black caricature, we must shift our focus to popular performances, such as minstrelsy. This requires a move away from canonical texts, such as novels, to other cultural works. Those texts that are more ephemeral - such as theatrical performances, cartoons, and private papers - prove here to be valuable cultural sources. Attending to these other forms of textuality allows us to see how pervasive was the English interest in "black" Americana. The "evidence" for the argument that Englishmen were connected intimately to "black women" would be difficult to marshall if one were to rely solely on canonized Victorian literature. (10)

The first half of Brody's book is indeed breathtakingly interdisciplinary and wideranging in a way that we need if we are going to really open up this field of British black Victorian studies. In her first chapter, "Miscegenating Mulattaroons," Brody reads an 1808 novel entitled The Woman of Colour, Thackeray's Vanity Fair, and Dion Bouci- 
cault's play The Octoroon, or Life in Louisiana. Brody offers some interesting observations about the "seeping quality of the colonial enterprise that has 'infected' the hearts and homes of England" (41) that resonate with the work I've discussed already, particularly Meyer's identification in Jane Eyre of what she calls a discourse of contagion or contamination (81-83). In the second chapter, Brody looks at Alexandre Dumas père's novel, The Black Tulip; Hiram Powers's sculpture of The Greek Slave, shown in England at the Great Exhibition of 1851; various minstrel versions of Uncle Tom's Cabin; a minstrel play called Flip, Flap, Flop; and Alexandre Dumas fils's novel, La Dame aux Camélias, and play, Camille.

In general, Brody wants to argue that blackness is deployed in the service of constructing white, male Englishness. So, for example, she writes that "the entire practice of blackface minstrelsy as it was performed in England had everything to do with the construction of Englishness as white" (85). As an overall argument, the latter seems reasonable, if a little broad. That broadness erupts rather banally at moments in the text, as, for example, when Brody insists that "purity and hybridity are therefore mutually constitutive rather than mutually exclusive" and then pronounces that "Pure purity is an impossibility" (67). The unwieldy breadth of the argument also makes itself felt when Brody jumps from one historical moment to another with no explanation. At one point, Brody moves from discussing various minstrel versions of Uncle Tom's Cabin, focusing on the "six-month period between September 1852 and February 1853" (75) to Flip, Flap, Flop, a minstrel play produced in 1883 , with little to mark the historical gap, except her point that "where some of the earlier narratives dealt with the difficulties of marrying the black daughter ... minstrels increasingly concerned themselves with the problems of marrying white daughters across race and class" (82). The intervening Jamaica Rebellion and Indian Mutiny notwithstanding, Brody seems willing to draw a rather simple line through the century in terms of representations of blackness and of what she terms "miscegenating mulattaroons" (16). Elsewhere, Brody notices a shift in the overall narrative of blackness as she is telling it, but she doesn't seem to pay that shift much attention. Brody notes that Rhoda Swartz's character "marks a significant change from the sentimental narratives exemplified by The Woman of Colour, where the mulattaroon serves as the main focus of the book and is offered the possibility of salvation" (28). But this observation doesn't ultimately lead Brody anywhere, nor does it cause her to ask, as I might have liked her to have done, "why this change?" In the end, these two chapters are jammed full of interesting material and interesting readings, but ultimately, the story Brody is telling here about this material does not seem as historically precise as it might be.

In the second half of the book, the historical narratives seem to recede into the background, as Brody falls back on examining a few literary texts without any real explanation for why they deserve exclusive focus. A chapter on Charles Reade's play, Masks and Faces, examines femininity as performance, androgyny, and the instability of gender categories so that Brody can argue that "gender, no less than race, is performative" (98). It is a thoughtful chapter that ought to develop a finer conclusion. Moreover, it is not clear why this chapter belongs in a book that is focused on why the English became "white" nor how this chapter connects with the work in the first half of the book. Lamentably, the chapter never turns to the interplay between gender and race in Reade's work (an issue which has remained unexamined in Victorian scholarship). 
The discussions of H. G. Wells and Bram Stoker are in some ways the most satisfying pieces of this book, partly because they are self-contained and coherent literary readings, and it strikes me that Brody is more comfortable when she is discussing literary texts. The work on Wells in particular is long overdue. Brody argues convincingly that The Island of Dr. Moreau "registers as well as reinscribes the belief that the fate and status of the English race itself is in jeopardy of becoming monstrously hybrid, blackened, and feminized" (130), and her discussion of Moreau is certain to become the starting point for all future work on Wells. But her assertion that this novel "reflects the pervasiveness of the hybrid anxiety documented as being an important aspect of much Victorian discourse" (130) seems once again to be too broad and is unsupported in the chapter itself. For while Brody briefly investigates Victorian scientific thought on the relationship between man and beast in order to understand Wells's deployment of the hybrid, she elides man/animal hybridity with interracial hybridity and with monogenesist and polygenist arguments about the nature of the relationship between races. With all these balls in the air, Brody misses the important point for her discussion of historical sources for Moreau that it was George Gordon's mulatto identity that underlined his dangerousness as leader of the populist uprising in Morant Bay, Jamaica.

Impossible Purities is, finally, a wide-ranging and always interesting book that seems to me unevenly successful. Brody deserves much credit for insisting on the importance of blackness, particularly what she calls “'black' Americana” (10) to Victorian culture, but I wish she herself had paid more attention to this subject. Reading Impossible Purities, I was struck with the fact that Brody crammed so much fascinating and relatively unexamined material into her first and second chapters and then lavished so much attention on the better known works of Wells and Stoker in the second half of the book.

Deirdre David's Rule Britannia: Women, Empire, and Victorian Writing forms a contrast to Meyer's Imperialism at Home and Brody's Impossible Purities. Like Meyer, David is interested in the way gender shapes "writing the nation" (5), how writing by and about women "created that nation-defining construction on which the sun was said never to set: the British empire" (4). Like Brody's, her book ventures beyond the canonical, investigating the "cultural documents [which] worked to create, explain, and negotiate the difficulties attendant upon possession of an immense and always changing empire" (8).

Her first chapter considers the "imagery of invasion and counterinvasion" (10) as Emily Eden, sister to a governor-general in India in the late 1830s, writes of the European presence in India and wonders why the 3,000 Indian mountaineers beside the 150 picnicking Europeans "do not cut all our heads off, and say nothing more about it" (40). David contrasts Eden's private letters with Macaulay's well-known "parliamentary rhetoric of colonial conquest and pacification" and reads both in connection with Wilkie Collins's The Moonstone. She concludes that a "woman writing letters to [her] sister and a journal [for herself]" has no "need to silence a voice that might call into question the moral authority of imperial invasion" and thus that "Victorian gender politics assists in a negotiation of the brutal material facts of Britannic rule" (42). At the same time, in her second and third chapters, David finds, through an examination of Dickens's The Old Curiosity Shop and Dombey and Son and Brontë's Jane Eyre, "intimate, constitutive relationships between fragile, pale Englishwomanhood and demonic, African savagery, and between domestic tyranny and colonial subjugation" (10). In a discussion that includes a range of material from travel narratives about Jamaica to sensationalist literature 
about Indian suttee, David argues that Little Nell, Florence Dombey, and Jane Eyre are all shaped by "physical misery" and "formed by the Victorian gender codes of female sacrifice" (116).

David's fourth chapter investigates a fascinating legal case "concerning loose behavior on the part of a woman missionary" (10) alongside discussion of the debate about education of the English by Indian natives, the emergence of the "babu figure in English Raj culture" (11) and the war waged by the British on "thuggee" (135). As David explains, Mary Pigot, an unmarried English female missionary was charged with indiscretion for unseemly behavior after sitting too close to Kalicharan Banerjee, a Christian teacher at her orphanage in Calcutta. Among other things, Pigot was ultimately charged with "being a 'hybrid' Eurasian" (123) but she filed counter charges for defamation and was ultimately awarded "three thousand rupees in damages with costs" (148). David reads this case, alongside The Moonstone once again and, briefly, A Passage to India, in order to consider the importance to Victorian imperial patriarchy of female propriety in coping with the "recurrent difficulty in all Victorian colonial practice" (123) of maintaining civil governance over a militarily subjugated people.

In her sixth chapter, David looks at late-Victorian writing including Haggard's King Solomon's Mines and She, and also Tennyson's relatively unexamined "poems of empire" (11) in order to consider the "contemporaneous fear that the laboring body of the native and the laboring body of the British woman were taking on a rebellious life of their own" (11). In her final chapter, she considers the character of Emila Gould in Conrad's Nostromo as one more instance of "the built-in interrogation of imperialism often allotted to women throughout the history of Victorian empire" (214).

Of her methodology, David explains that throughout her book, she has "incorporated a close reading of nonfictional texts ... into my analysis of fiction to claim a confluence at certain historical moments in the Victorian period of powerful and prevailing ideas about gender and race in culture and society" (10). Rule Britannia is indeed a dense, scholarly book that works hard to argue for these moments of "confluence." Whereas Brody's examination of her materials sometimes feels anecdotal or incompletely justified, David's research is both more thorough and more thoroughly integrated into her readings. That said, it is also true that David's book is somewhat less ambitious in scope. Her chapters remain organized primarily around one or two canonical texts, and the discussion of nonfictional work is driven by this focus. In the end, while Rule Britannia investigates a lot of interesting material, including, for example, the bizarre case of Pigot, the book also provides some less exciting content, such as yet another reading of Jane Eyre (albeit a thoughtful one). With so much material still almost totally unexamined in the Victorian period, such as the minstrel shows about Uncle Tom's Cabin to which Brody pays muchdeserved attention, I can't help feeling a little disappointed to read one more discussion of Jane Eyre or She.

The final book that I want to examine at length here is H. L. Malchow's Gothic Images of Race in Nineteenth-Century Britain. Malchow is an historian, and it's informative to see the difference in how an historian negotiates the issue of selecting materials from which to form an argument about Victorian culture. With its attention to a wide number of popular and canonical literary and non-literary texts, Gothic Images strikes me as an interdisciplinary study in the best sense of the word. But Malchow is surprisingly defensive about this issue. He warns that his book relies on "a relatively small number of texts" (7) 
and offers his work as a "tentative sampling of a vast field of popular culture, a field in which an ephemeral novel or play, sensational for a season and then forgotten, can hold as much meaning as the familiar artifacts of the Victorian intelligentsia" (4). I wish more Victorian literary critics who are interested in making arguments about Victorian culture and race would leave aside Malchow's caution but take strongly to heart his plea to unlock the vast field of popular culture instead of focusing so exclusively on the intelligentsia.

In Gothic Images, Malchow argues that race in Victorian England was structured by a "racial gothic' discourse" (2). The gothic genre offered a language of "terror, disgust, [and] alienation" (3), which became interwoven into the "language of race" (232). The book is structured to alternate between gothic fiction and racial and imperial discourse. The first chapter reads Mary Shelley's Frankenstein in the context of Caribbean slavery and unrest, and is, I think, an important contribution to Shelley scholarship and our overall understanding of the novel (while Frankenstein may be a book that everyone reads and talks about, like Jane Eyre, the issue of slavery in Shelley's novel has received scant critical attention). The second focuses on the gothic discourse of cannibalism and of the primitive non-white. The third chapter draws on biographical details and cultural history to read Bram Stoker's Dracula in the context of "sexual-cum-racial pollution" (6), homosexual panic, and anti-Semitism. The fourth chapter examines the discourse of the halfbreed, while the epilogue examines the press-driven panic over interracial intimacy at the "Savage South Africa" Exhibition of 1899 (240).

The discussion of the half-breed may be Malchow's most important contribution. Unlike Brody's discussion of the "miscegenating mulattaroon," Malchow's is carefully structured around what he calls three "imperial theaters": "India before and after 1857, Jamaica during the Gordon 'rebellion' of 1865, and the Canadian West during the Riel or Metis rebellion of 1870 and 1885" (199). This multinational and multiracial organization allows for a nuanced and precise description of the "shift away from the view that half-breeds were at least useful tools in the spread of British rule and culture toward one that construed them to be, at best, marginal and irrelevant, and at worst dangerous instruments of pollution and sedition" (199-200). Malchow's work here on the half-breed is likely to be far more influential than Brody's, and his book ranks for me as one of the most important texts about the Victorians and race in the last decade.

In retrospect, it may seem as if British black studies in the Victorian period has been enormously productive of late. Perhaps so. But what I have tried to show in my discussion of the books above is that the work in this field is still widely uneven. Some scholars, like Gikandi, write with the assumption that their audience still knows very little about the field, and I fear this assumption may be justified. Certainly there is a consensus among the books I have discussed about the importance of studying issues of race and empire in order to understand the ways in which white Englishness was established as a seemingly unified and immutable identity. But beyond that larger point, there are many questions that remain unanswered in a field that continues to be painted with a very broad brush. Moreover, as so many of the books continue to reinvestigate some of the same canonical texts, we don't necessarily move forward in our larger understanding of Victorian culture and society.

Deirdre David sounds a completely opposite note to my pessimism here when she writes that the "critical and theoretical work of intellectuals such as Edward Said, Gayatri Spivak, and Homi Bhabha since the late 1970s has laid the groundwork for what is now 
an established and rapidly growing field of critical and theoretical inquiry. Dissertations abound on topics in postcolonial literatures and black British studies" (11). I am not so sanguine. Perhaps all these dissertations are not showing up yet as books. Or perhaps, we just need to wait a few years for more of them to make their way out of the publishing pipelines.

Perhaps David is right about the established nature and popularity of the field. But from my viewpoint, having read the books I have read and done the research I have done, I would like to close by supporting all those young scholars out there who perhaps feel discouraged that dissertations on black British studies are a dime a dozen. The field remains young and vastly under-investigated. We need your work. Keep at it.

New Jersey City University

\section{WORKS CONSIDERED}

Brantlinger, Patrick. Rule of Darkness: British Literature and Imperialism, 1830-1914. Ithaca: Cornell UP, 1988.

Brody, Jennifer DeVere. Impossible Purities: Blackness, Femininity and Victorian Culture. Durham: Duke UP, 1998.

David, Deirdre. Rule Britannia: Women, Empire, and Victorian Writing. Ithaca: Cornell UP, 1996.

Fryer, Peter. Staying Power: The History of Black People in Britain. London: Pluto P, 1984.

Gikandi, Simon. Maps of Englishness: Writing Identity in the Culture of Colonialism. New York: Columbia UP, 1996.

Hall, Catherine. White, Male and Middle Class: Explorations in Feminism and History. Cambridge: Polity P, 1992.

Lewis, Reina. Gendering Orientalism: Race, Femininity and Representation. London: Routledge, 1996.

Lorimer, Douglas. Colour, Class, and the Victorians: English Attitudes to the Negro in the Mid-Nineteenth Century. London: Leicester UP, 1978.

Malchow, H. L. Gothic Images of Race in Nineteenth-Century Britain. Stanford, Stanford UP, 1996.

McClintock, Anne. Imperial Leather: Race, Gender and Sexuality in the Colonial Context. New York: Routledge, 1995.

Meyer, Susan. Imperialism at Home: Race and Victorian Women's Fiction. Ithaca: Cornell UP, 1996.

Renk, Kathleen J. Caribbean Shadows and Victorian Ghosts: Women's Writing and Decolonization. Charlottesville: UP of Virginia, 1999.

Said, Edward. Culture and Imperialism. New York: Knopf, 1993.

Young, Robert J. C. Colonial Desire: Hybridity in Theory, Culture and Race. New York: Routledge, 1995. 